Journal of Tropical Ecology

http://journals.cambridge.org/TRO

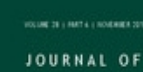

Additional services for Journal of Tropical Ecology:

Email alerts: Click here

Subscriptions: Click here

Commercial reprints: Click here

Terms of use : $\underline{\text { Click here }}$

\title{
Differential seed germination of a keystone palm (Euterpe edulis) dispersed by avian frugivores
}

Abraão de Barros Leite, Pedro H. S. Brancalion, Roger Guevara and Mauro Galetti

Journal of Tropical Ecology / Volume 28 / Issue 06 / November 2012, pp 615 - 618

DOI: 10.1017/S0266467412000594, Published online: 22 November 2012

Link to this article: http://journals.cambridge.org/abstract_S0266467412000594

How to cite this article:

Abraão de Barros Leite, Pedro H. S. Brancalion, Roger Guevara and Mauro Galetti (2012). Differential seed germination of a keystone palm (Euterpe edulis) dispersed by avian frugivores. Journal of Tropical Ecology, 28, pp 615-618 doi:10.1017/

S0266467412000594

Request Permissions : Click here 


\title{
SHORT COMMUNICATION
}

\section{Differential seed germination of a keystone palm (Euterpe edulis) dispersed by avian frugivores}

\author{
Abraão de Barros Leite*, Pedro H. S. Brancalion†, Roger Guevarał and Mauro Galetti*11 \\ * Departamento de Ecologia, Universidade Estadual Paulista (UNESP), 13506-900 Rio Claro, SP, Brazil \\ $\dagger$ Universidade de São Paulo, Departamento de Ciências Florestais, Piracicaba, SP, Brazil \\ $\ddagger$ Instituto de Ecologia, A.C., Red de Biologia Evolutiva, Carretera Antigua a Coatepec 351, Congregación El Haya, Xalapa, Ver. 91070, México \\ (Accepted 2 September 2012)
}

Key Words: Aburria cujubi, Atlantic forest, frugivory, gut passage time, Pteroglossus bailloni, Ramphastos dicolorus, Ramphastos toco, Ramphastos vitellinus, seed dispersal, seed fate, Turdus rufiventris

The effectiveness of seed dispersal by vertebrates has been analysed by examining both quantitative and qualitative components (Jordano \& Schupp 2000, Schupp et al. 2010). While the quantitative component is relatively easily assessed in the field (e.g. visitation rate, number of fruits eaten per visit), the qualitative component (e.g. fate of dispersed seeds, seed treatment in the digestive system of the disperser) is rarely studied under natural conditions, because it is difficult to measure the effects on seeds once ingested by the dispersers (Cortes et al. 2009).

Many studies have found that seed passage through animal digestive tracts increases the chances of germination of seeds of a large number of plant species (Traveset \& Verdu 2002). However, a limitation to interpreting such findings in an ecological context is that, in many experiments, different types of frugivore are considered as equals, even when they have different digestive physiologies and behaviours while eating and discharging seeds (Traveset \& Verdu 2002). For instance, frugivorous birds can either regurgitate or defecate the ingested seeds, depending on the relative bird-toseed size ratio (Gasperin \& Pizo 2012, Levey 1987). In neotropical forests, large-bodied frugivores, such as cracids (Cracidae), usually defecate seeds, while smallbodied bird species regurgitate them. From the dispersed seeds' perspective, the outcome of being defecated or regurgitated by a bird has a direct effect on its probability of germination. Defecated seeds can be deposited at

\footnotetext{
${ }^{1}$ Corresponding author. Email: mgaletti@rc.unesp.br
}

greater distances from the mother plant, because they remain for longer period in the disperser's digestive tract, while regurgitated seeds spend less time and therefore can be discharged near or even below the mother plant (Jordano et al. 2007). However, defecated seeds are deposited in clumps with faecal material and usually have pulp attached to the seeds, conditions that may favour the proliferation of fungi and bacteria that may kill the seed (Meyer \& Witmer 1998). In contrast regurgitated seeds are deposited singly and are totally defleshed (Howe 1989). Therefore, it is important to uncover the fate of seeds dispersed by different types of frugivore in order to assess their effectiveness as seed dispersers, particularly because of the current accelerated phenomenon of defaunation (i.e. extirpation of largebodied species, and its trophic consequences, Dirzo \& Miranda 1991), it is critical to understand how different animal species perform some of these functions.

Here, we compared seed germination of a keystone palm (Euterpe edulis Martius, Arecaceae) after being either defecated or regurgitated by frugivorous birds. Euterpe edulis is the dominant subcanopy tree in the Atlantic forest in Brazil, Argentina and Paraguay (Henderson et al. 1995). In pristine Atlantic forests with no palm-heart harvesting, this palm species can represent up to $20 \%$ of trees with girth at breast height $>15 \mathrm{~cm}$ (Brancalion et al. 2011). Euterpe edulis produces single-seeded fruits with seed diameter ranging from 6.3 to $14.6 \mathrm{~mm}$ dispersed by 39 species of bird ranging from thrushes (Turdus spp., with mean gape size of $12 \mathrm{~mm}$ ) to large toucans (Ramphastos spp., with mean gape size of $30 \mathrm{~mm}$ ) (Galetti et al. 1999). 
We offered ripe fruits of E. edulis to six species of bird: three large frugivorous toucans (body mass ranging from 500-860 g, Ramphastos toco Statius Muller, R. dicolorus L., R. vitellinus Lichtenstein, and one small toucanet (mean body mass $139 \mathrm{~g}$, Pteroglossus bailloni Vieillot) that regurgitated E. edulis seeds, one small frugivorous thrush that also regurgitated seeds (mean body mass $60 \mathrm{~g}$, Turdus rufiventris Vieillot), and one large frugivorous guan that defecated seeds (mean body mass $1200 \mathrm{~g}$, Aburria cujubi Pelzeln). We collected the seeds and set up a germination experiment just after seeds were discharged by the birds (i.e. without any cleaning treatment). In addition, we also included in the germination experiment manually defleshed seeds and seeds embedded in the pulp. Feeding trials and the germination experiment were carried out at Parque Ecológico de São Carlos, a zoo in São Carlos, Brazil. Each bird species was maintained in a large aviary and fed on a diet of bananas, papayas and other fruits ad libitum. Fruits of E. edulis were offered early in the morning, and the defecated or regurgitated seeds were retrieved after $2 \mathrm{~h}$.

We collected a total of 631 seeds either regurgitated or defecated by birds and tested for germination. Toucans and thrushes regurgitated Euterpe seeds after approximately $30 \mathrm{~min}$ and seeds were totally defleshed, while guans defecated the seeds after $1 \mathrm{~h}$ and some pulp was attached to the seed still. All seeds ingested/discharged by birds together with two types of control seed (manually defleshed seeds and seeds with the pulp attached), were placed in dishes filled with sand in a greenhouse under controlled temperature and water regime. We followed the fate of seeds individually, and after $12 \mathrm{wk}$ we compared the germination curves and the overall proportion of seeds germinated among all treatments. Germination was evaluated based on the emergence of the button (a swollen body abutting the seed surface resulting from the emergence of a small portion of the cotyledon) (Queiroz 1986).

The Cox proportional hazard regression model with the Efron approximation to deal with tied germination times was fitted to the data and revealed significant differences in germination curves among treatments (Figure 1). We found three groups based on the final germination ratios: seeds with pulp manually removed and seeds regurgitated by small frugivores ( $T$. rufiventris and $P$. bailloni), seeds regurgitated by large toucans (Ramphastos toco, $R$. dicolorus and $R$. vitellinus), and seeds with pulp and defecated by the piping guan (A. cujubi) (Figure 1). The germination curves of seeds with pulp and those defecated by A. cujubi did not differ significantly $(\mathrm{z}=1.7$, $\mathrm{P}=0.08)$ and had the lowest germination percentage. In contrast, manually defleshed seeds together with those regurgitated by the two smallest frugivores, T. rufiventris and P. bailloni, had the highest germination percentage. Nonetheless, the model showed no significant difference

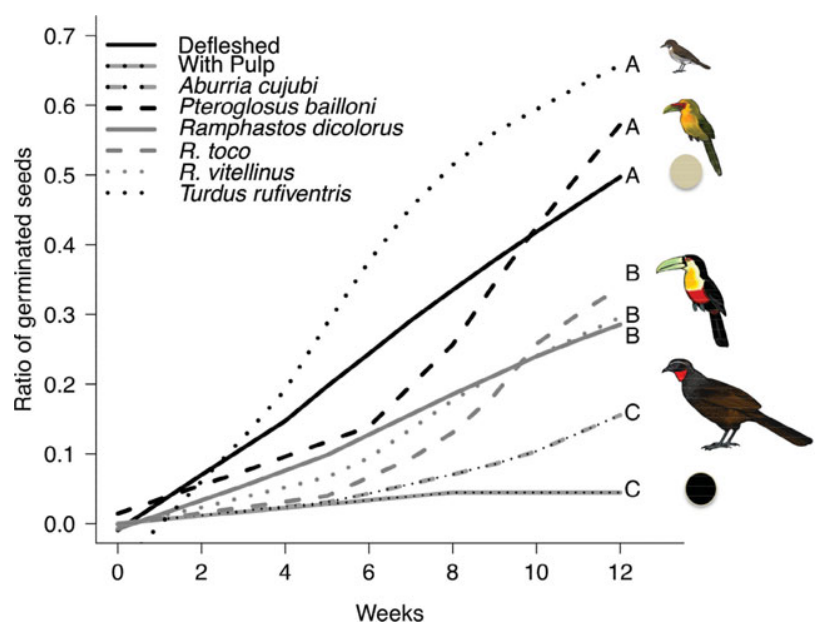

Figure 1. (Colour online) Germination curves of seeds of Euterpe edulis ingested and defecated (Aburria cujubi), regurgitated (Pteroglossus bailloni, Ramphastos dicolorus, R. toco, R. vitellinus and Turdus rufiventris), and control seeds (with no pulp removed (black seed) and manually defleshed (cream seed) kept under control conditions. The same letters represents groups with no significant difference in germination probability at week 12 . To facilitate the graphical perception all lines were smoothed with the robust locally weighted regression algorithm, LOWESS (Cleveland 1981).

between the germination curves of manually defleshed seeds and those discharged by T. rufiventris $(\mathrm{z}=1.7$, $\mathrm{P}=0.0891$ ) and these differed significantly from the germination curve of seeds regurgitated by $P$. bailloni $(\mathrm{z}=$ $4.7, \mathrm{P}<0.0001$ ) for which germination only commenced in earnest during week six (Figure 1).

Our results showed that defleshing of E. edulis seeds is important for germination and different bird species have different effects on the speed and overall germination percentage of E. edulis. Cracids have been reported as important seed dispersers in tropical forests (Galetti et al. 1997, Munoz \& Kattan 2007), but for the particular case of E. edulis, however, A. cujubi delayed the germination of most seeds comparable to the performance of nondispersed seeds (with pulp). Also it is worth noting that the most effective dispersers, in terms of germination probability of discharged seeds, were the two smallest frugivores tested (T. rufiventris and P. bailloni), while the overall germination probability of seeds regurgitated by the three large toucans (0.30) was only half that of seeds discharged by T. rufiventris and P. bailloni (0.58). Given that E. edulis are recalcitrant (Martins et al. 1999) and may take up to $6 \mathrm{wk}$ for complete germination in chambers (Queiroz 1986), and the germination curves of the seeds in our study stabilized $10 \mathrm{wk}$ after sowing, we believe that the monitoring period of $12 \mathrm{wk}$ was sufficient. Meyer \& Witmer (1998) also found that the most important distinction between regurgitated and defecated seeds was the negative effect of faeces associated with defecated seeds on germination, suggesting that in some circumstances, 
seed defecation may be less beneficial to plants than regurgitation.

The mechanisms that produce these differences may depend on the seed treatment given by each bird species. The retention time of seeds in the digestive system is longer in the cracid compared with thrushes, toucanets and toucans. The abrasive treatment of E. edulis seed given by cracids may damage the base of the embryo, which is quite exposed in E. edulis (Aguiar \& Mendonça 2003). Besides these two treatments given to seeds by different bird species, the fact that defecated seeds still had attached pulp may be another factor affecting germination, perhaps promoting seed-borne pathogens that will rot the embryo.

Our findings also have important implications for seed dispersal in defaunated or fragmented tropical forests. While large toucans and toucanets are usually locally extinct in heavily hunted or small forest fragments, thrushes and guans are more resilient (dos Anjos et al. 2011, Willis 1979), therefore the seeds dispersal of a keystone palm such as E. edulis will have to rely only on thrushes.

In conclusion, the type of treatment applied by each avian frugivore to seeds, and not only the quantitative dispersal components, has to be taken into account when evaluating seed dispersal effectiveness. This may be challenging in field experiments, particularly in tropical systems where the frugivore assemblage is often diverse (Donatti et al. 2011). Also, in a broader context, selective extirpation of large seed dispersers of E. edulis from Atlantic forest remnants seems not to represent a threat to the germination of seeds of this keystone palm, since the small frugivores provide the best seed treatment for germination.

\section{ACKNOWLEDGEMENTS}

We would like to thank the staff and the director of the São Carlos Zoo for allowing us to carry out our experiments and M. Takaki for help in the germination experiments. We would also like to thank FAPESP (BIOTA Program, 2007/03392-6 and 2010/04927-3) for the financial support and for providing a fellowship for the first author. $\mathrm{MG}$ receives a fellowship from CNPq. Bird plates were done by Carl Buell.

\section{LITERATURE CITED}

AGUIAR, M. O. \& MENDONÇA, M. S. 2003. Morfo-anatomia da semente de Euterpe precatoria Mart. (Palmae). Revista Brasileira de Sementes 25:37-42.

BRANCALION, P. H. S., NOVEMBRE, A. D. L. C. \& RODRIGUES, R. R. 2011. Seed development, yield and quality of two palm species growing in different tropical forest types in SE Brazil: implications for ecological restoration. Seed Science and Technology 39:412-424.
CLEVELAND, W. S. 1981. LOWESS: A program for smoothing scatterplots by robust locally weighted regression. American Statistician 35:54.

CORTES, M. C., CAZETTA, E., STAGGEMEIER, V. G. \& GALETTI, M. 2009. Linking frugivore activity to early recruitment of a bird dispersed tree, Eugenia umbelliflora (Myrtaceae) in the Atlantic rainforest. Austral Ecology 34:249-258.

DIRZO, R. \& MIRANDA, A. 1991. Altered patterns of herbivory and diversity in the forest understory: a case study of the possible consequences of contemporary defaunation. Pp. 273-287 in Price, P. W., Lewinshon, T. M., Fernandes, G. W. \& Benson, W. W. (eds.). Plant-animal interactions: evolutionary ecology. John Wiley \& Sons, New York.

DONATTI, C. I., GUIMARAES, P. R., GALETTI, M., PIZO, M. A., MARQUITTI, F. M. D. \& DIRZO, R. 2011. Analysis of a hyper-diverse seed dispersal network: modularity and underlying mechanisms. Ecology Letters 14:773-781.

DOS ANJOS, L., COLLINS, C. D., HOLT, R. D., VOLPATO, G. H., MENDONCA, L. B., LOPES, E. V., BOCON, R., BISHEIMER, M. V., SERAFINI, P. P. \& CARVALHO, J. 2011. Bird species abundanceoccupancy patterns and sensitivity to forest fragmentation: implications for conservation in the Brazilian Atlantic forest. Biological Conservation 144:2213-2222.

GALETTI, M., MARTUSCELLI, P., OLMOS, F. \& ALEIXO, A. 1997. Ecology and conservation of the jacutinga Pipile jacutinga in the Atlantic forest of Brazil. Biological Conservation 82:31-39.

GALETTI, M., ZIPPARRO, V. B. \& MORELLATO, L. P. C. 1999. Fruiting phenology and frugivory on the palm Euterpe edulis in a lowland atlantic forest of Brazil. Ecotropica 5:115-122.

GASPERIN, G. \& PIZO, M. A. 2012. Passage time of seeds through the guts of frugivorous birds, a first assessment in Brazil. Revista Brasileira de Ornitologia 20:48-51.

HENDERSON, A., GALEANO, G. \& BERNAL, R. 1995. Field guide to the palms of the Americas. Princeton University Press, Princeton. 363 pp.

HOWE, H. F. 1989. Scatter- and clump-dispersal and seedling demography: hypothesis and implications. Oecologia 79:417-426.

JORDANO, P. \& SCHUPP, E. W. 2000. Seed disperser effectiveness: the quantity component and patterns of seed rain for Prunus mahaleb. Ecological Monographs 70:591-615.

JORDANO, P., GARCIA, C., GODOY, J. A. \& GARCIA-CASTANO, J. L. 2007. Differential contribution of frugivores to complex seed dispersal patterns. Proceedings of the National Academy of Sciences USA 104:3278-3282.

LEVEY, D. J. 1987. Seed size and fruit-handling techniques of avian frugivores. American Naturalist 129:471-485.

MARTINS, C. C., NAKAGAWA, J. \& BOVI, M. L. A. 1999. Desiccation tolerance of four seedlots from Euterpe edulis Mart. Seed Science and Technology 28:1-13.

MEYER, G. A. \& WITMER, M. C. 1998. Influence of seed processing by frugivorous birds on germination success of three North American shrubs. American Midland Naturalist 140:129-139.

MUNOZ, M. C. \& KATTAN, G. H. 2007. Diets of cracids: how much do we know? Ornitologia Neotropical 18:21-36.

QUEIROZ, M. H. 1986. Botão germinativo do palmiteiro como indicador da germinação. Revista Brasileira de Sementes 8:55-59. 
SCHUPP, E. W., JORDANO, P. \& MARIA GOMEZ, J. 2010. Seed dispersal effectiveness revisited: a conceptual review. New Phytologist 188:333-353.

TRAVESET, A. \& VERDU, M. 2002. A meta-analysis of the effect of gut treatment on seed germination. Seed dispersal and frugivory: ecology, evolution and conservation. Pp. 339-350 in Levey, D.
J., Silva, W. \& Galetti, M. (eds.). Seed dispersal and frugivory: ecology, evolution and conservation. CABI Books, Wallingford. $511 \mathrm{pp}$.

WILLIS, E. O. 1979. The composition of avian communities in remanescent woodlots in southern Brazil. Papeis Avulsos Zoologia 33:1-25. 